overhand op de ideologische en minder anti-socialistisch georiënteerde christen-democraten uit België, Italië en Nederland, zeker toen de Italiaanse christen-democraten medio jaren negentig eclipseerden. De opvolgers van de Italiaanse partners, Berlusconi en zijn 'onduidelijke figuren' (381), bleek een slechte ruil voor het CDA. De facto verloor het CDA niet alleen de principiële discussie, maar voegde het zich gedurende het proces inhoudelijk bovendien meer en meer naar de Europese zusterpartijen. De analyse van deze laatste - mijns inziens belangrijker, maar sluipender - ontwikkeling gaat in dit boek schuil achter de aandacht voor de poging van het CDA de rug principieel recht te houden.

Had het anders kunnen lopen? Genoemde Oostlander was vanaf 1975 betrokken bij de Europese samenwerking en bij de opstelling van diverse partijprogramma's. Zijn minachting voor de conservatieven was niet gering en zijn bezwaar altijd principieel — en dus ononderhandelbaar. Maar ook de overige onderhandelingsposities concentreerden zich volgens Van Kessels relaas nog sterk op de beginselen voor de Europese politiek en resulteerden in niet meer dan een katterig gevoel over de feitelijke ontwikkeling die in Duitse zin verliep.

George Harinck

S. Scagliola, Last van de oorlog. De Nederlandse oorlogsmisdaden in Indonesië en hun verwerking (Dissertatie Rotterdam 2002; Amsterdam: Balans, 2002, 447 blz., ISBN 905018593 2).

Dit Rotterdamse proefschrift heeft tot onderwerp het militaire geweld aan Nederlandse zijde tijdens de Indonesische onafhankelijkheidsstrijd in de jaren 1945-1949 plus de latere debatten daarover. Auteur Stef Scagliola heeft intellectuele moed; zij koos een maatschappelijk relevant onderwerp dat nog altijd gevoelig ligt in het publieke sfeer. Het boek begint sterk met een heldere samenvatting van de strijd zelf. Citaten uit egodocumenten verlevendigen het beeld, dat al bekend was uit de literatuur, en brengen de ervaring dichtbij. Juist die egodocumenten, die met name vanaf de jaren tachtig verschenen, leveren de auteur fraaie illustraties voor de vele vormen van geweld aan beide zijden van de frontlinies. In het eerste deel stelt Scagliola de tegenstelling tussen de 'watjes' van de Koninklijke Landmacht en 'bloeddorstige' Indonesische militairen van het Indisch leger, het KNIL, op overtuigende wijze ter discussie. Eén ding wordt duidelijk: ook KL-soldaten beoefenden zinloos en disproportioneel geweld, zij het uiteraard niet allemaal en niet overal. Daarvoor is de term 'oorlogsmisdaad' de juiste. Het ging veelal om misdaden die nu voor het Humanitair Strafhof in Den Haag behandeld zouden worden. De Excessennota, die in 1969 als regeringsreactie op en vijf maanden na het tv-optreden van Joop Hueting verscheen, bevatte slechts het officieel gerapporteerde topje van de ijsberg, zoals Van Doorn en Hendrix al in 1970 stelden. ${ }^{1}$

Dat blijkt ook nu uit de verhalen die Scagliola tijdens haar onderzoek hoorde, en uit een deel van de brieven die zij analyseerde: 885 aan de VARA, de omroep die in januari 1969 de Achter het Nieuws-uitzending met Hueting presenteerde, en 46 aan Lou de Jong uit 1987.

Na een kort overzicht van de geschiedenis van de debatten, komt Scagliola daar per beroepsgroep op terug. Zij analyseert het gedrag van de groepen die het debat beheersten: politici, historici en veteranen. Een vierde groep, de journalisten, laat zij conform diens mediërende rol tussen deze groepen doorfietsen. Politici en historici worden afgerekend op de ijkpunten 'taboe' en 'doofpot' bij het ontstaan en de ontvangst van de Excessennota. Voor historici beoor- 
deelt de auteur bovendien de totstandkoming van de bronnenpublicatie De NederlandsIndonesische betrekkingen 1945-1950 in 1969, en drie andere publicaties: Ontsporing van geweld van Van Doorn en Hendrix (1970), De Zuid-Celebes-affaire van Willem IJzereef (1984) en deel XII van L. de Jong's Het Koninkrijk der Nederlanden in de Tweede Wereldoorlog (1987). Voor veteranen en veteranenorganisaties is er een andere meetlat, die van 'trauma'.

Die structuur levert nogal wat herhaling op: de Excessennota komt vier keer ter sprake, deel XII van Het Koninkrijk driemaal. De conceptuele chaos neemt geleidelijk toe, evenals het aantal morele oordelen. Pregnante definiëring van begrippen blijft achterwege. Het begrip doofpot laat weinig te raden over: een bewuste poging om een zaak verborgen te houden. Maar wat is taboe? De Van Dale is prettig eenvoudig: 'dat waarover volgens de sociale conventie niet gesproken mag worden.' Scagliola grijpt echter terug op theorieën van sociologen en constateert op grond daarvan 'sporen van taboeïsering' bij politici en historici. Met de openheid van de archieven zat het in 1969 wel goed. Bronnen in Indonesië werden echter niet getraceerd en dat werd om politieke redenen — de precaire verhouding met Indonesië — ook onwenselijk geacht. Brieven van militairen aan Achter het Nieuws bleven eveneens buiten beeld.

Het is evenwel de vraag of dat laatste wijst op taboe of doofpot. Daarvan is immers alleen sprake als de onderzoekers wisten dat de brieven - met een negatieve lading voor de opdrachtgever - bestonden en als zij de brieven daarom hebben verzwegen. Via een enkel telefoontje aan de secretaris van de onderzoekscommissie, C. Fasseur, had de auteur kunnen weten dat dat eerste niet het geval was. Gezien de concentratie op ambtelijke archieven was hier dan ook geen sprake van taboe of doofpot, hoogstens van een beperkt onderzoek. Het is mooi dat Scagliola de brieven heeft opgespoord en geanalyseerd, haar logica is op dit punt echter niet sterk.

De auteur neemt tenslotte afstand van de beroepsethiek van de historicus. De daarbij horende neutraliteit en afstandelijkheid zijn volgens haar de redenen geweest dat de geruchtmakende onderzoeken van Van Doorn/Hendrix en IJzereef nooit het grote publiek hebben bereikt. Hun boeken hadden op dat moment weinig nieuwswaarde en zijn dan ook niet door de media opgepikt. Dat verwijt richt Scagliola opmerkelijk genoeg niet tot de media, maar tot de eigen beroepsgroep. Hun neutraliteit is volgens haar een 'immuniseringsstrategie'. Daarom roept zij historici op de denkkaders te doorbreken door te schokken, hun resultaten te 'chargeren, de grens op [te] zoeken en het risico van veroordeling door vakgenoten te lopen.' (361) In het eindoordeel over de verschillende beroepsgroepen en hun houding ten aanzien van oorlogsmisdaden krijgen historici dus de Zwarte Piet uitgereikt.

De veteranen die met geweld te maken kregen, blijven namelijk buiten schot, als het om 'taboe' of 'doofpot' gaat. Zij worden immers gewogen naar de categorie van het 'trauma'. Het laat zich raden wat toetsing van hun gedrag aan de eerdere ijkpunten zou hebben opgeleverd: de moeizame debatten over het onderwerp in militaire kring uit de jaren tachtig en negentig zijn bekend. Met de introductie van 'trauma' treedt echter ineens een opvallende paradigmawisseling op. Deze wordt niet methodologisch onderbouwd. De enige logica achter deze keuze lijkt het publieke debat, waar trauma immers geleidelijk het nieuwe modewoord werd, zoals Jolande Withuis onlangs heeft aangetoond. De schrijver Rudy Kousbroek figureert dan ook prominent in de inleiding, want hij was het die de begrippen taboe en doofpot rond het koloniale verleden introduceerde en die de militairen een strategisch gebruik van het begrip trauma verweet.

Trauma is echter in het boek een nog gecompliceerder begrip dan taboe en doofpot. Scagliola onderscheidt een drietal verschillende vormen: een 'metaforisch trauma', een 'medisch-psy- 
chologisch trauma' en een 'strategisch trauma'. Het eerste zouden alle militairen hebben opgelopen bij de kille ontvangst en de vervreemding bij terugkomst, 'de gedeelde ervaring van miskenning en teleurstelling.' Het resulteert in een dramatisch opgerekt traumabegrip, dat de term elke inhoud ontneemt. Onder de medisch-psychologische noemer analyseert Scagliola een aantal interessante rapporten van psychiaters uit de jaren veertig over de groep getraumatiseerden. Onder 'strategisch trauma' verstaat zij het slachtofferschap dat in het raam van de groeiende publieke populariteit van die categorie werd gebruikt om genoegdoening en erkenning te verkrijgen. Deze functionele vorm van trauma blijkt volgens Scagliola meer een uitvinding van journalisten dan van veteranen zelf. In de bij het proefschrift gevoegde stellingen is tenslotte ook nog sprake van een 'historisch trauma van Nederland' dat pas verwerkt is, wanneer alle feiten op tafel liggen, aan Indonesische en aan Nederlandse kant. Dat voorspelt weinig goeds voor de Nederlandse volksgezondheid. Met een zekere kennis van het eigen koloniaal verleden met inbegrip van het gehanteerde geweld zouden we misschien al een heel eind komen.

Mijn conclusie: conceptuele inconsistentie haalt dit vlot geschreven boek over een belangrijk onderwerp inhoudelijk onderuit. Men leze het op zijn sterke punten, zoals de samenvatting van de militaire geschiedenissen, de informatieve beschrijving van de debatten, de analyse van de psychiatrische rapporten uit de periode 1945-1949 en van de ingezonden brieven. Die bieden interessante stof tot nadenken over de Nederlandse identiteit. De moraliserende oordelen kunnen worden gemist. En laten historici hun onderzoeksresultaten op wetenschappelijk verantwoorde en consistente wijze presenteren, zeker als zij schokkend zijn. Daar heeft het publiek juist in onze emotiecultuur recht op.

Elsbeth Locher-Scholten

1 J. A. A. van Doorn, W. J. Hendrix, Ontsporing van geweld. Over het Nederlands/Indisch/Indonesisch conflict (Rotterdam, 1970). De Excessennota. Nota omtrent het archiefonderzoek naar de gegevens omtrent excessen in Indonesië begaan door Nederlandse militairen in de periode 1945-1950, Jan Bank, ed. (Den Haag, 1995). 


\section{2-2002. De Guldensporenslag en zijn nagalm in de moderne tijd ${ }^{1}$}

\section{P. C. M. HOPPENBROUWERS}

Terwijl 11 juli voor rechtgeaarde Ollanders een dag van rouw is - de dag nadat de Vader des Vaderlands door moordenaarshand werd omgebracht - is het bij de zuiderburen feest. Op 11 juli 1302 behaalden ze hun grootste militaire overwinning ooit in de Guldensporenslag voor de poorten van Kortrijk. Een eeuw geleden, bij de zeshonderdjarige herdenking van dit wapenfeit, was '1302' in Vlaamssprekend België uitgegroeid tot een historisch identificatiepunt van de eerste orde waarvoor men massaal de straat op ging. ${ }^{2}$ In 2002 was dat allemaal wat minder, maar helemaal ongemerkt is de elfde juli zeker niet voorbijgegaan. Dat was mede te danken aan historici die de gelegenheid hebben aangegrepen om het collectieve geheugen der Belgen op eigentijdse wijze op te poetsen, dus niet meer door op nationale trots te tamboeren maar veeleer door zoveel mogelijk verschillende, bij voorkeur nieuwe, en in elk geval allemaal wetenschappelijk gefundeerde interpretaties van 1302 aan te reiken aan een breed publiek dat geïnteresseerd is in het verleden van het eigen land. Die interpretaties hebben niet meer uitsluitend betrekking op de gebeurtenissen zelf en de directe historische context waarin die lagen ingebed, of op hun oorzaak en hun gevolg, maar (vooral) ook op de wording van 1302 tot een wezenlijk onderdeel van de nationale mythevorming in zowel België als Vlaanderen. Het betekent tevens dat de studie van de Guldensporenslag inmiddels niet meer uitsluitend het terrein is van mediëvisten van allerlei slag (historici, medioneerlandisten, archeologen); daarnaast eisen vertegenwoordigers van de politieke geschiedenis van de moderne tijd en van de cultuuren ideeëngeschiedenis een plaats op. Dat alleen al maakt de berg literatuur die in 2002 is verschenen en waarvan hier slechts een deel wordt besproken, tot boeiende lectuur. $^{3}$

\footnotetext{
1 In dit artikel worden de volgende publicaties besproken: C. Billen, e. a., 1302 Revisité/1302 Herbekeken (Brussel: IMAVO, 2003, 177 blz., ISBN 907536817 8). M. de Bruijn, Ch. Broer, Volc te voet. Gevolgen van de Guldensporenslag voor de opkomst van de burgerij in de Noordelijke Nederlanden (Volkscultuur XIV; Utrecht: Nederlands Centrum voor Volkscultuur, 2002, 63 blz., ISBN 907184053 0). R. C. van Caenegem, ed., 1302. Feiten en mythen van de Guldensporenslag (Antwerpen: Mercatorfonds, 2002, 301 blz., ISBN 906153 516 6). G. H. Nörtemann, Im Spiegelkabinett der Historie. Der Mythos der Schlacht von Kortrijk und die Erfindung Flanderens im 19. Jahrhundert (Dissertatie Universität Bielefeld 2002; Berlijn: Logos Verlag, 2002, 492 blz., ISBN 383250081 2). P. Trio, D. Heirbaut, D. van den Auweele, ed., Omtrent 1302 (Alfred Cauchie reeks IV; Leuven: Universitaire pers Leuven, 2002, 269 blz., ISBN 90 5867208 5). J. F. Verbruggen, R. Falter, 1302. Opstand in Vlaanderen (Tielt: Lannoo, 2001, 278 blz., ISBN 9020944126 ).

2 In het vervolg zal ik, net als veel andere auteurs, '1302' en 'Kortrijk' kortheidshalve gebruiken om de gebeurtenissen in Vlaanderen rond 1300 en hun verwerking in de latere geschiedschrijving, literatuur en beeldende kunsten aan te duiden.

3 De complete oogst aan literatuur - voor een belangrijk deel bestaande uit heruitgaven - is te vinden op de website www.liebaart.org.
} 